\title{
sciendo

\section{An Experimental Optimization Research of Methyl and Ethyl Esters Production from Safflower Oil}

\author{
Mert GULUM ${ }^{1 *}$, Atilla BILGIN² \\ ${ }^{1,2}$ Mechanical Engineering Department, Karadeniz Technical University, Trabzon, Turkey
}

\begin{abstract}
Nowadays, biodiesel is drawing attention as a renewable and clean alternative to fossil diesel fuel because of numerous advantages such as higher flash point, cetane number and density. However, the high viscosity of biodiesel is one of the critical shortcomings and it causes poor atomization, decrease in engine performance and increase in exhaust emissions. To overcome this shortcoming, in this study, the effects of main transesterification reaction variables on the viscosities of produced safflower oil methyl and ethyl esters (biodiesel) were investigated as a full factorial experimental design, and optimum parametric values giving the lowest viscosity were determined. Density and viscosity were measured according to ISO 4787 and DIN 53015 standards. Sodium ethoxide $\left(\mathrm{C}_{2} \mathrm{H}_{5} \mathrm{ONa}\right)$ was utilized as a catalyst, and 90 and 120 minutes of reaction duration were kept constant for methanolysis and ethanolysis reactions. According to the results, the optimal reaction parameters were determined as: $0.75 \%$ catalyst concentration, 8:1 alcohol to oil molar ratio and $56{ }^{\circ} \mathrm{C}$ reaction temperature for methanolysis; $1.00 \%$ catalyst concentration, $12: 1$ alcohol to oil molar ratio and $70{ }^{\circ} \mathrm{C}$ reaction temperature for ethanolysis. Based on the reaction parameters, the methyl and ethyl esters were produced with the lowest viscosities of $3.989 \mathrm{~mm}^{2} / \mathrm{s}$ and $4.393 \mathrm{~mm}^{2} / \mathrm{s}$, respectively. In the light of results obtained in this study, similar studies on production of biodiesels from different oils and alcohols can be performed.
\end{abstract}

Keywords - Biodiesel; ethyl ester; methyl ester; optimization; renewable energy; sodium ethoxide; transesterification; vegetable oils

\section{INTRODUCTION}

In recent years, research and development of alternative fuels has attracted considerable attention because of limitation of conventional fossil resources, increasing of their prices and rising concern over greenhouse gas emissions [1]. Biodiesel, defined by ASTM as "a fuel comprised of mono-alkyl esters of long-chain fatty acids derived from vegetable oils or animal fats" [2], offers many important benefits over fossil diesel fuel such as:

- Higher flash point temperature making it safer to handle and store;

- Higher cetane number resulting in a shorter ignition delay period and thus smoother operation with lower noise emissions;

- Excellent lubricity property following longer engine component life;

- Reduced toxicity and exhaust emissions (especially $\mathrm{CO}, \mathrm{CO}_{2}, \mathrm{SO}_{\mathrm{x}}, \mathrm{HC}$ and smoke);

- Higher biodegradability;

- Renewability characteristic [3]-[8].

However, there are also important disadvantages of biodiesel such as:

- Higher copper strip corrosion;

- Lower heating value requiring more fuel to produce the same power and thus increasing

* Corresponding author.

E-mail address: gulum@ktu.edu.tr 
fuel consumption;

- High manufacturing cost;

- Lower oxidative stability because of un-saturation degree in chemical structure;

- Generally, slightly higher $\mathrm{NO}_{\mathrm{x}}$ emissions;

- Relatively poor performance in cold temperatures due to lower volatility;

- Higher viscosity resulting in poor fuel atomization and air-fuel mixing quality, incomplete combustion, and thus lower engine performance and increasing exhaust emissions [3]-[8].

Chemically speaking, there are mainly three chemical methods in biodiesel production such as micro-emulsion, thermal cracking (pyrolysis) and transesterification [9]. Among these methods, the most widespread one is transesterification (alcoholysis) in which a monohydric alcohol (generally methanol or ethanol) reacts with fatty acids of triglycerides (vegetable oil) to form glycerol (by-product) and the corresponding fatty acid alkyl esters [6]. The reaction can be catalyzed using homogeneous (acid or base) or heterogeneous (acid, base or enzyme) catalyst. Generally, the base-catalyst (i.e. basic transesterification) ensures a better reaction rate in a relatively short time for the triglycerides including the lower amount of free fatty acids while acid-catalyst (i.e. esterification) is suggested before transesterification for the triglycerides containing higher free fatty acids [6]. Although the reaction rate in conversion of triglyceride to biodiesel is relatively slow for the enzyme-catalyzed reaction [6], the main advantages of enzymatic catalysis over base or acid catalysis are: (i) transesterification reaction at ever lower temperatures can be performed, (ii) the ester yield is relatively higher and (iii) it is not necessary to purify the produced biodiesel [10]. Moreover, methanol and ethanol as monohydric alcohol are mostly used in the transesterification. Methanol is generally preferred because of having the shortest chain and lower cost [10]. Ethanol is also used because of the many advantages such as: (i) it can be produced from renewable resources, thus decreasing dependence from petroleum-based alcohols such as methanol, (ii) it is less toxic, (iii) biodiesels produced using ethanol have higher energy content, cetane number and oxidation stability [11]. Several optimization studies on methyl or ethyl ester production from different feedstocks using basic or acidic catalyst were performed in existing literature such as: Berchmans and Hirata [12] produced methyl ester from Jatropha curcas seed oil including $15 \%$ free fatty acid. In biodiesel production, firstly, the esterification reaction was carried out at the reaction temperature of $50^{\circ} \mathrm{C}$ and by using methanol to oil molar ratio of $0.60 \mathrm{w} / \mathrm{w}$ and $\mathrm{H}_{2} \mathrm{SO}_{4}$ amount of $1 \% \mathrm{w} / \mathrm{w}$ for one hour. After the reaction, the free fatty acid value of oil reduced to less than $1 \%$. Then, transesterification of the pre-treated oil was carried out at $65{ }^{\circ} \mathrm{C}$ and by using methanol to oil amount of $0.24 \mathrm{w} / \mathrm{w}$ and sodium hydroxide to oil amount of $1.4 \% \mathrm{w} / \mathrm{w}$ for 2 hours to produce biodiesel with $90 \%$ ester yield. In the study performed by Tiwari et al. [13], some reaction parameters (methanol amount, acid concentration and reaction time) were optimized using Response surface methodology (RSM) to reduce the free fatty acid value of Jatropha oil $(14 \pm 0.5 \%)$ to about $1 \%$. The researchers used quadratic polynomial equations in RSM to predict acid value. The optimum reaction variables were determined as: $\mathrm{H}_{2} \mathrm{SO}_{4}$ concentration of $1.43 \% \mathrm{v} / \mathrm{v}$, methanol to oil molar ratio of $0.28 \mathrm{v} / \mathrm{v}$, reaction duration of 88 minutes and reaction temperature of $60{ }^{\circ} \mathrm{C}$ for esterification reaction while methanol/pre-treated oil molar ratio of $0.16 \mathrm{v} / \mathrm{v}$, reaction duration of 24 minutes and reaction temperature of $60^{\circ} \mathrm{C}$ for transesterification reaction providing the average biodiesel yield more than $99 \%$. Sirisomboonchai et al. [14] investigated the effects of temperature, reaction duration, methanol amount and catalyst loading amount on conversion of waste cooking oil to biodiesel produced using calcined scallop shell as a catalyst. According to the results, the optimum reaction variables providing over $86 \%$ ester yield were defined as: catalyst amount of $5 \%$, alcohol to oil 
molar ratio of $6: 1$, reaction temperature of $65^{\circ} \mathrm{C}$, reaction duration of $120 \mathrm{~min}$, and calcination temperature of $1000{ }^{\circ} \mathrm{C}$ for scallop shell. The catalyst was used for four cycles while the ester yield decreased to about $20 \%$, however, it was specified that calcined scallop shell is thought to be an alternative as a low-cost catalyst for the biodiesel industry. Eevera et al. [15] optimized transesterification reaction variables (catalyser amount $(0.5,1.0,1.5,2.0$ and $2.5 \mathrm{wt}$. \%), methanol amount $(120,150,180,210$ and $240 \mathrm{~mL})$, reaction duration $(30,60,90,120$ and $150 \mathrm{~min}$.$) and$ reaction temperature $\left(40,45,50,55\right.$ and $\left.\left.60{ }^{\circ} \mathrm{C}\right)\right)$ to produce the highest ester yield biodiesel from some edible and non-edible oils. Some important fuel properties (specific gravity, moisture content, etc.) of optimized biodiesels were also measured. According to the results, the optimum reaction variables of edible oils were determined as: reaction duration of $90 \mathrm{~min} ., 180 \mathrm{~mL}$ of methanol for $1000 \mathrm{~mL}$ of oil, sodium hydroxide amount of $1.5 \mathrm{wt} . \%$ and reaction temperature of $50{ }^{\circ} \mathrm{C}$. These variables were determined to be similar to the non-edible oils' parameters except the methanol amount $(210 \mathrm{~mL} / 1000 \mathrm{~mL}$ of oil). Moreover, all biodiesels are determined to be generally suitable to the related international standards. There are also numerous studies on optimization of transesterification reaction variables to produce biodiesel having the highest methyl or ethyl ester yield, however, parametric research on production of the lowest viscosity methyl or ethyl ester are rarely carried out in the existing literature. Therefore, the importance of this study is to synthesize the lowest viscosity safflower oil methyl and ethyl ester for solving the high viscosity problem of biodiesel in a way mentioned above, and thus increasing the use of biodiesel in the world. For this, the effects of main reaction variables (sodium ethoxide amount of $0.75 \%, 1.00 \%$ and $1.25 \%$; reaction temperature of $50{ }^{\circ} \mathrm{C}, 55{ }^{\circ} \mathrm{C}$ and $60{ }^{\circ} \mathrm{C}$ for methanolysis, $60{ }^{\circ} \mathrm{C}, 65{ }^{\circ} \mathrm{C}$ and $70{ }^{\circ} \mathrm{C}$ for ethanolysis; and alcohol to oil molar ratio of 3:1, 6:1 and 9:1 for methanolysis, 9:1, 12:1 and 15:1 for ethanolysis) on viscosities of produced biodiesels were systemically investigated as a full factorial experimental design, and the reaction variables giving the lowest viscosity were determined. Reaction durations of 90 and 120 minutes were kept constant for methanolysis and ethanolysis reactions, respectively. Safflower oil was chosen as feedstock because of its high potential and low-cost in Turkey.

\section{EXPERIMENTAL STUDY}

\subsection{Materials, Reaction Parameters and Biodiesel Production}

Refined safflower oil, sodium ethoxide $\left(\mathrm{C}_{2} \mathrm{H}_{5} \mathrm{ONa}\right)$, pure ethanol $\left(\mathrm{C}_{2} \mathrm{H}_{5} \mathrm{OH}\right)$, pure methanol $\left(\mathrm{CH}_{3} \mathrm{OH}\right)$ and anhydrous sodium sulphate were utilized in biodiesel production. The following reaction variables were investigated such as:

- $\mathrm{C}_{2} \mathrm{H}_{5} \mathrm{ONa}$ concentration, \%: $0.75,1.00$ and 1.25 ;

- Reaction temperature for methanolysis, ${ }^{\circ} \mathrm{C}: 50,55$ and 60 ;

- Reaction temperature for ethanolysis, ${ }^{\circ} \mathrm{C}: 60,65$ and 70 ;

- Methyl alcohol/oil molar ratio: 3:1, 6:1 and 9:1;

- Ethyl alcohol/oil molar ratio: 9:1, 12:1 and 15:1.

The parametric values were selected through detail investigation of existing literature [16]-[21]. It is noted that the reaction durations of 90 and 120 minutes were kept constant throughout all experiments since the values are determined to be optimum in the authors' previous studies [22], [23]. To investigate the effects of reaction parameters given above on viscosity as a full factorial experimental design, in this study, an experimental optimization of transesterification reaction was performed by producing $27(3 \cdot 3 \cdot 3)$ methyl and ethyl ester samples (totally 54 
samples). In biodiesel production, a certain amount of $\mathrm{C}_{2} \mathrm{H}_{5} \mathrm{ONa}$ depending on catalyst to oil concentration was dissolved into a certain amount of $\mathrm{CH}_{3} \mathrm{OH}\left(\right.$ or $\left.\mathrm{C}_{2} \mathrm{H}_{5} \mathrm{OH}\right)$ according to alcohol to oil molar ratio to prepare methoxide (or ethoxide) solution. The solution was blended with pre-heated safflower oil in a flask, and the reactants were mixed at a certain reaction temperature during 90 (or 120) minutes by means of a magnetic stirrer heater connected to a spiral reflux condenser and thermometer. The reaction temperature was controlled within a range of $\pm 1{ }^{\circ} \mathrm{C}$. After the reaction, in the refinement step of transesterification, the reaction mixture was first discharged to a separating funnel in order to cool to room temperature, after which two layers (ester and glycerol) were separated by gravity in 24 hours. The upper layer consists of methyl (or ethyl) ester while the lower layer contains glycerol, excess alcohol, remaining catalyst, soaps, some entrained esters and partial glycerides [24]. The upper layer (biodiesel) was cleaned up by hot water, dried using anhydrous sodium sulphate and filtered.

\subsection{Density and Viscosity Measurements}

Densities of pure esters at $15{ }^{\circ} \mathrm{C}$ and $40{ }^{\circ} \mathrm{C}$ were measured according to ISO 4787 standard by means of a pycnometer and top loading balance (accuracy of $\pm 0.01 \mathrm{~g}$ ). Their dynamic viscosities were also measured at $40{ }^{\circ} \mathrm{C}$ in accordance with DIN 53015 standard using a universal Haake Falling Ball Viscometer, Haake Water Bath, a stopwatch (accuracy of $\pm 0.01 \mathrm{~s}$ ) and a thermometer $\left( \pm 0.5^{\circ} \mathrm{C}\right)$. All measurements were repeated three times, and then their average was taken to minimize the measurement errors. As is well known, the kinematic viscosity was determined by dividing dynamic viscosity to the density at the same temperature. More details on the measurements can be also found in the authors' previous studies [3], [9], [11].

\subsection{Uncertainty Analysis}

Measured physical quantities are used to get targeted results in experimental studies. Uncertainties of measuring devices naturally cause uncertainties in the computed quantities, too. Uncertainty analysis allows to determine uncertainties in the targeted results to be aware of the reliability of them [3], [9], [11]. Therefore, in this study, uncertainty analysis of measured and calculated physical quantities such as dynamic and kinematic viscosities and densities were performed using the method proposed by Kline and McClintock [25]. According to this method, the highest uncertainty among all data was computed as $0.0249 \%$, showing the results are highly reliable and accurate. An example on the calculation of uncertainty analysis can also be found in [26].

\section{RESUlts AND DisCUSSION}

3D Fig. 1-3(a) and Fig. 4-6(a) show the changes in viscosities of methyl and ethyl esters with respect to reaction temperature and alcohol to oil molar ratio simultaneously for different catalyst concentrations $(0.75 \%, 1.00 \%$ and $1.25 \%$ respectively). In these figures, the points and lines indicate measured viscosity data (as listed in Appendix Table 1 and Table 2), and estimated viscosity values computed from cubic spline interpolation using Matlab software, respectively. The estimated values were determined based on the measured data. 


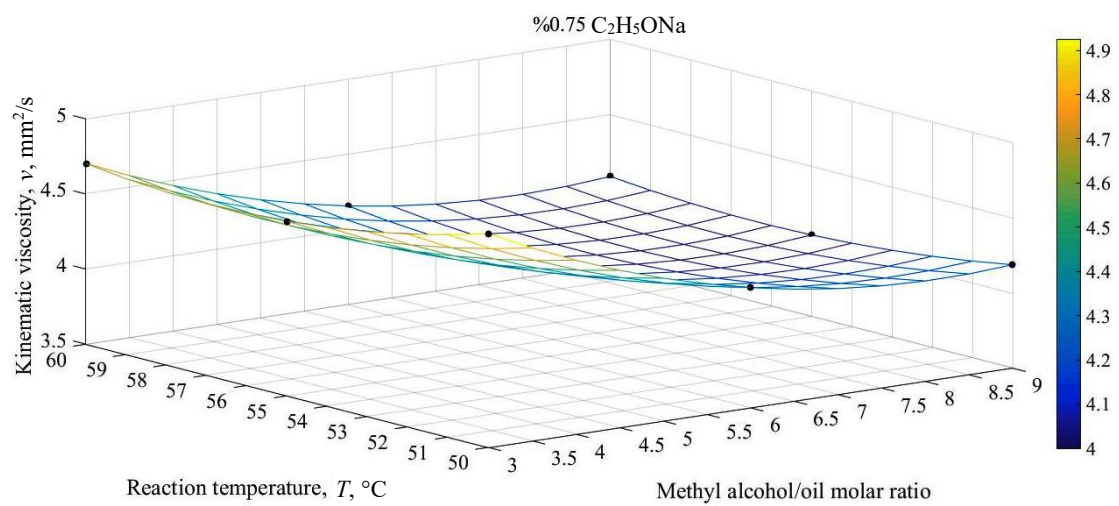

(a)

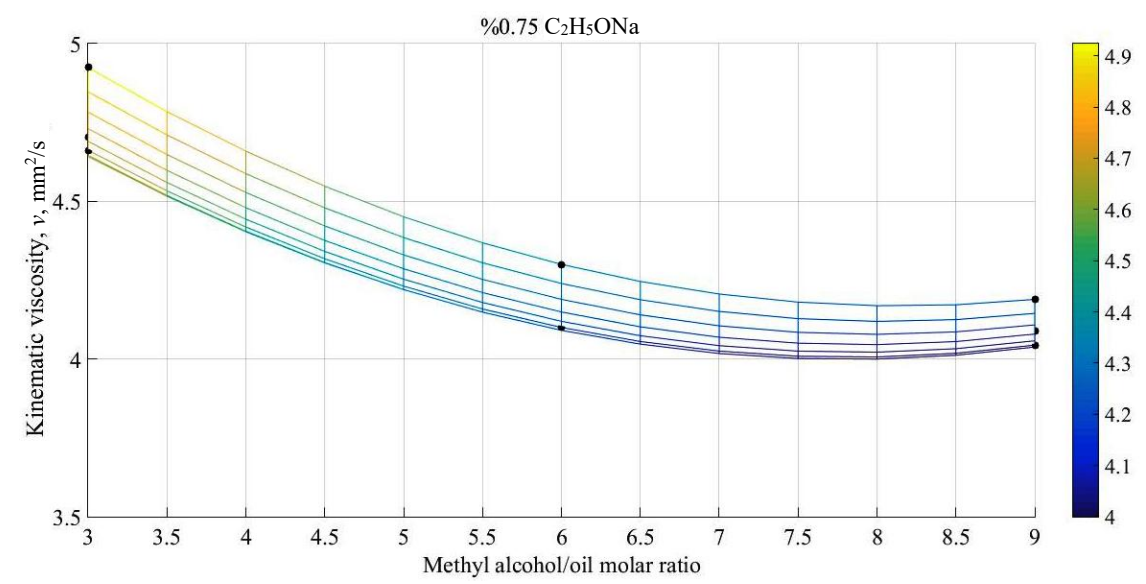

(b)

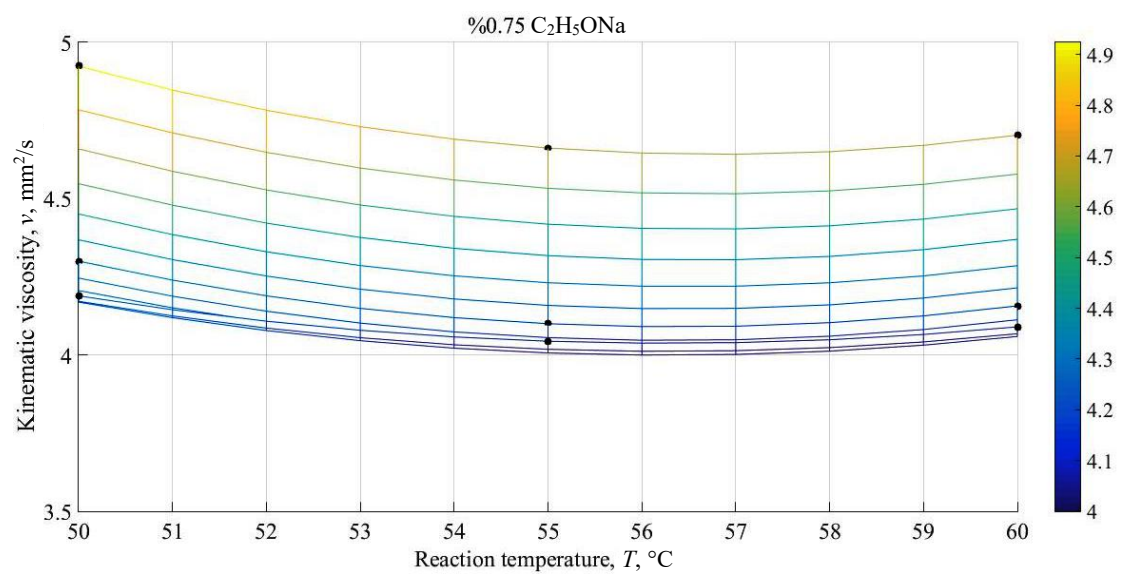

(c)

Fig. 1. Change of methyl ester viscosity (a) vs. reaction temperature and alcohol/oil molar ratio simultaneously; (b) alcohol/oil molar ratio; (c) reaction temperature for the catalyst concentration of $0.75 \%$. 


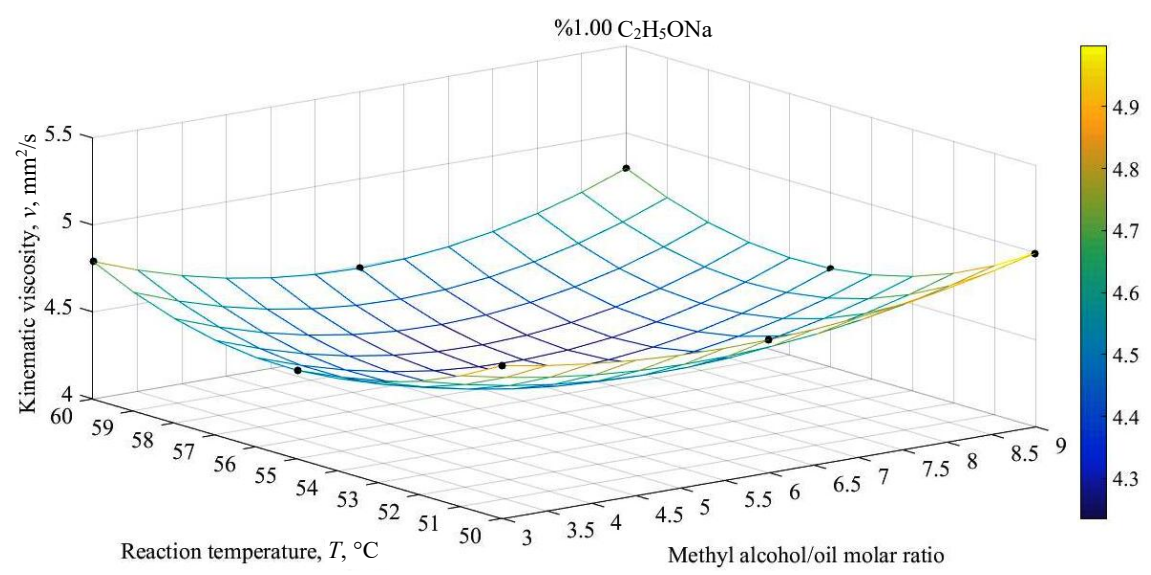

(a)

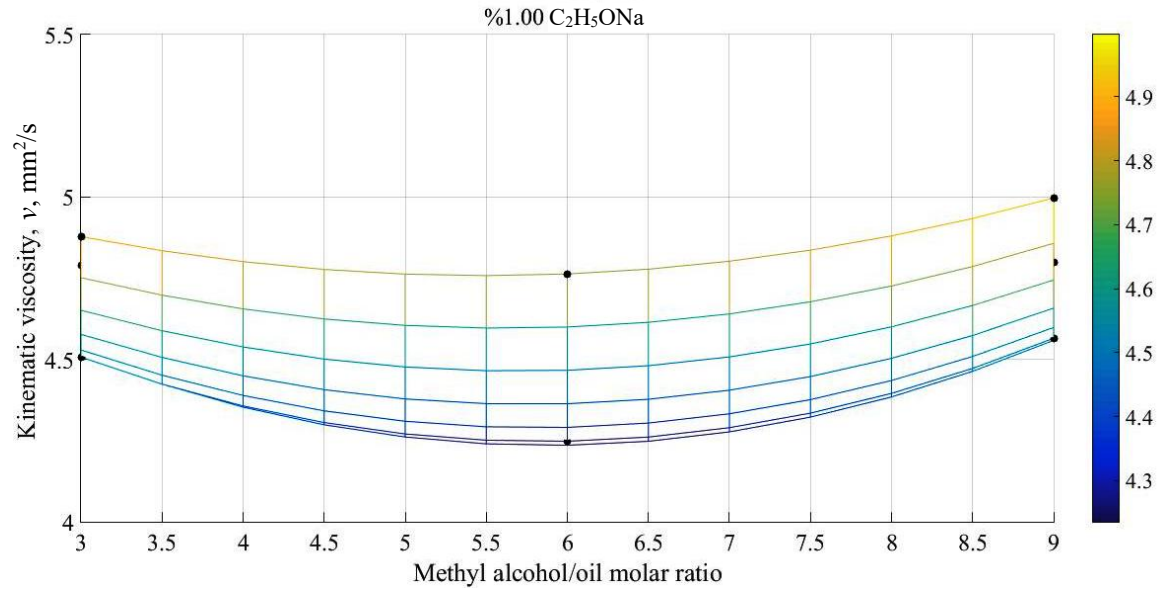

(b)

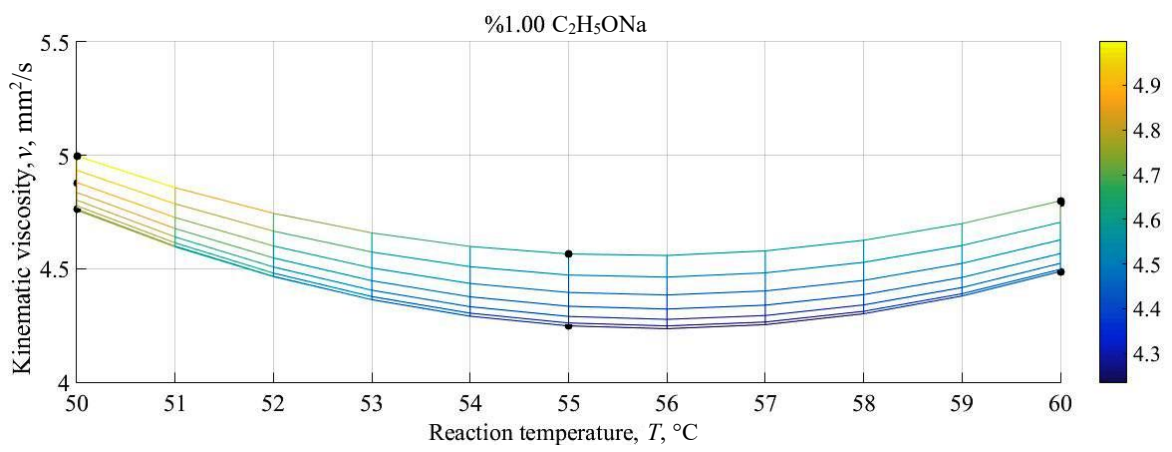

(c)

Fig. 2. Change of methyl ester viscosity (a) vs. reaction temperature and alcohol/oil molar ratio simultaneously; (b) alcohol/oil molar ratio; (c) reaction temperature for the catalyst concentration of $1.00 \%$. 
In this study, 2D Fig. 1-6(b, c) were also given to illustrate the individual effects of reaction temperature and alcohol to oil molar ratio on viscosities of methyl and ethyl esters for the use of different catalyst concentrations $(0.75 \%, 1.00 \%$ and $1.25 \%)$. As shown in 2D Fig. $1-6(\mathrm{~b})$, since the adequate biodiesel yield from transesterification is not obtained, viscosities of methyl and ethyl esters produced at lower alcohol ratios (such as $3: 1$ or 9:1) take higher values. As the molar ratio is increased, the transesterification, as an equilibrium reaction, shifts to ester side (i.e. reaction yield improves), viscosities decrease and take estimated minimum values of $3.9998 \mathrm{~mm}^{2} / \mathrm{s}$, $4.2356 \mathrm{~mm}^{2} / \mathrm{s}$ and $4.2862 \mathrm{~mm}^{2} / \mathrm{s}$ at $8: 1,6: 1$ and $6.5: 1$ methyl alcohol to oil molar ratios; and $4.4562 \mathrm{~mm}^{2} / \mathrm{s}, 4.3930 \mathrm{~mm}^{2} / \mathrm{s}$ and $4.4040 \mathrm{~mm}^{2} / \mathrm{s}$ at $13: 1,12: 1$ and $12: 1$ ethyl alcohol to oil molar ratios for $0.75 \%, 1.00 \%$ and $1.25 \%$, respectively. However, the higher alcohol to oil molar ratios (e.g. 9:1 for methanolysis and 15:1 for ethanolysis) result in increase in viscosities of methyl and ethyl esters because of deactivation in catalyst activity, emulsifier effect of $\mathrm{OH}^{-}$group, decrease in transesterification yield and increase in the solubility of glycerol in the ester phase. The viscosity values of methyl esters generally change in a narrower range in case of using $0.75 \%$ catalyst concentration, compared to $1.00 \%$ and $1.25 \%$, as shown in 2D Fig. 1-3(b). Moreover, viscosity values of ethyl esters change with respect to alcohol to oil molar ratio in a wider range at lower molar ratios $(9: 1)$ while vice versa at higher molar ratios $(12: 1$ or $15: 1)$ in case of using the catalyst concentration of $0.75 \%$, as shown in Fig. 4 (b). However, the change of viscosity vs. ethyl alcohol to oil molar ratio occurs in the about constant range for catalyst concentration of $1.00 \%$, as shown in Fig. 5(b), while it occurs in the firstly narrower, then wider, and finally again narrower ranges as molar ratio increases for catalyst concentration of $1.25 \%$, as shown in Fig. 6(b).

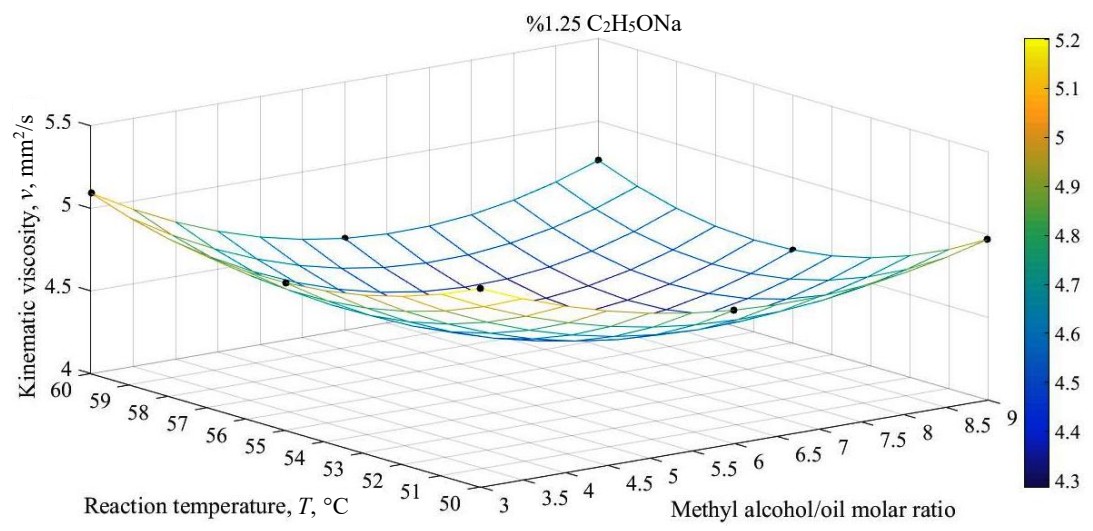

(a) 


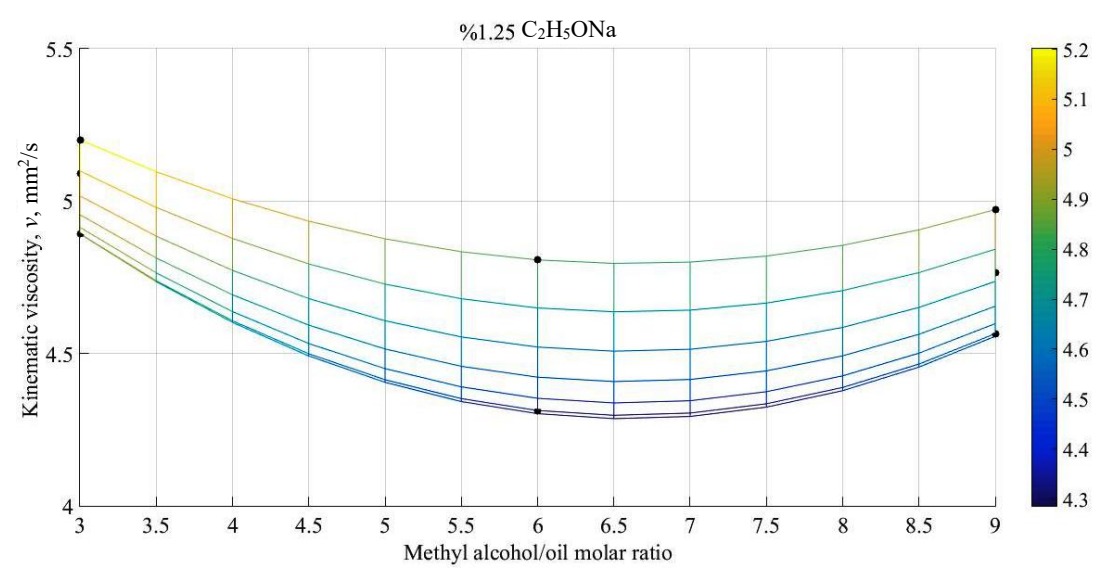

(b)

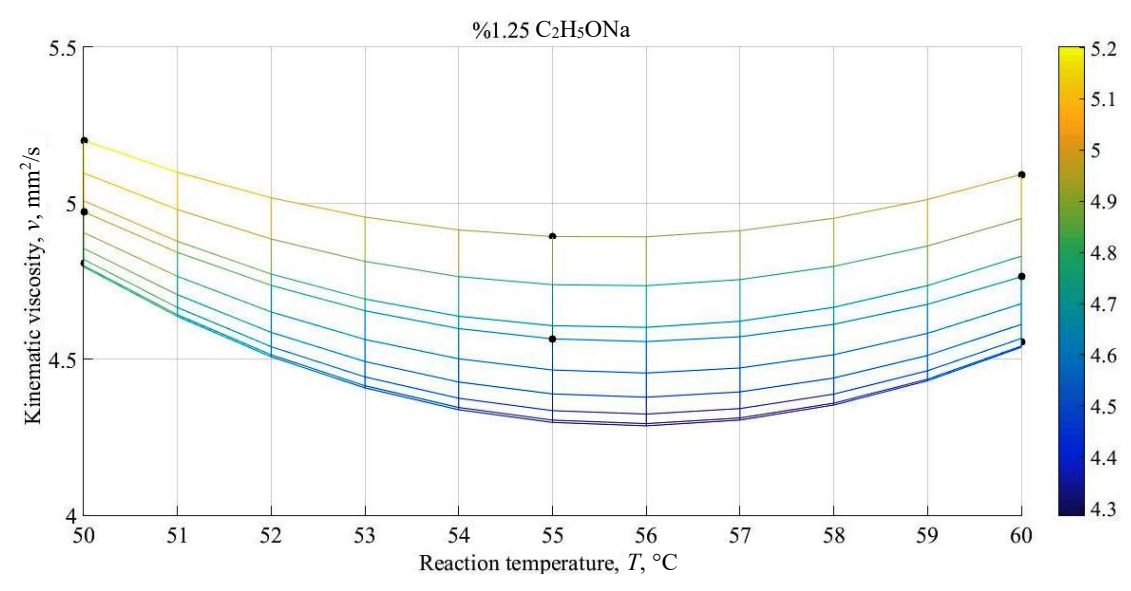

(c)

Fig. 3. Change of methyl ester viscosity (a) vs. reaction temperature and alcohol/oil molar ratio simultaneously; (b) alcohol/oil molar ratio; (c) reaction temperature for the catalyst concentration of $1.25 \%$.

The change of methyl ester viscosity is more clear in case of using $1.00 \%$ and $1.25 \%$ catalyst concentrations. In other words, variation in viscosity of methyl ester is slighter for catalyst concentration of $0.75 \%$ then $1.00 \%$ and $1.25 \%$, as seen in Fig. 1-3(a). In addition, variation in catalyst amount does not significantly affect the behavior of change in ethyl ester viscosity with respect to reaction temperature and alcohol/oil molar ratio simultaneously, as seen in Fig. 4-6(a). In other words, the similar characteristics in the viscosity change of ethyl esters were obtained for different catalyst amounts $(0.75 \%, 1.00 \%$ and $1.25 \%)$. As shown in these figures, methyl and ethyl esters having higher viscosity were produced at lower reaction temperatures (e.g. $50{ }^{\circ} \mathrm{C}$ for methanolysis and $60{ }^{\circ} \mathrm{C}$ for ethanolysis) and alcohol/oil molar ratios (e.g. 3:1 for methanolysis and 9:1 for ethanolysis). However, as temperature and molar ratio are increased until the specific parametric values, viscosity decreases and lowers to a minimum. However, after these parametric values, when temperature and molar ratio continue to increase, viscosity tends to increase as well. 


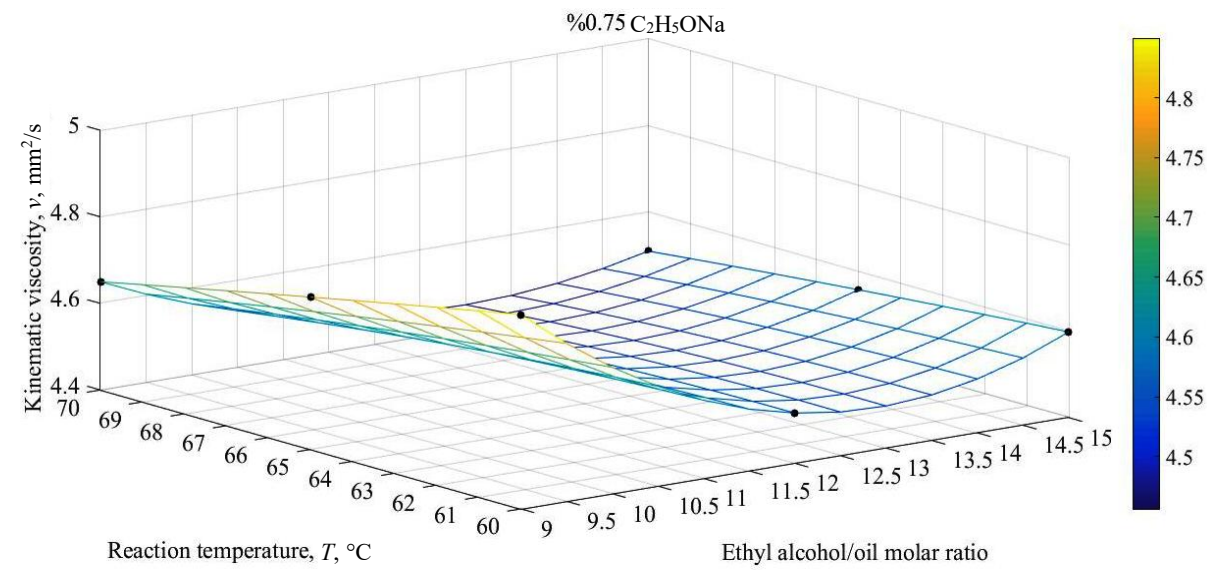

(a)

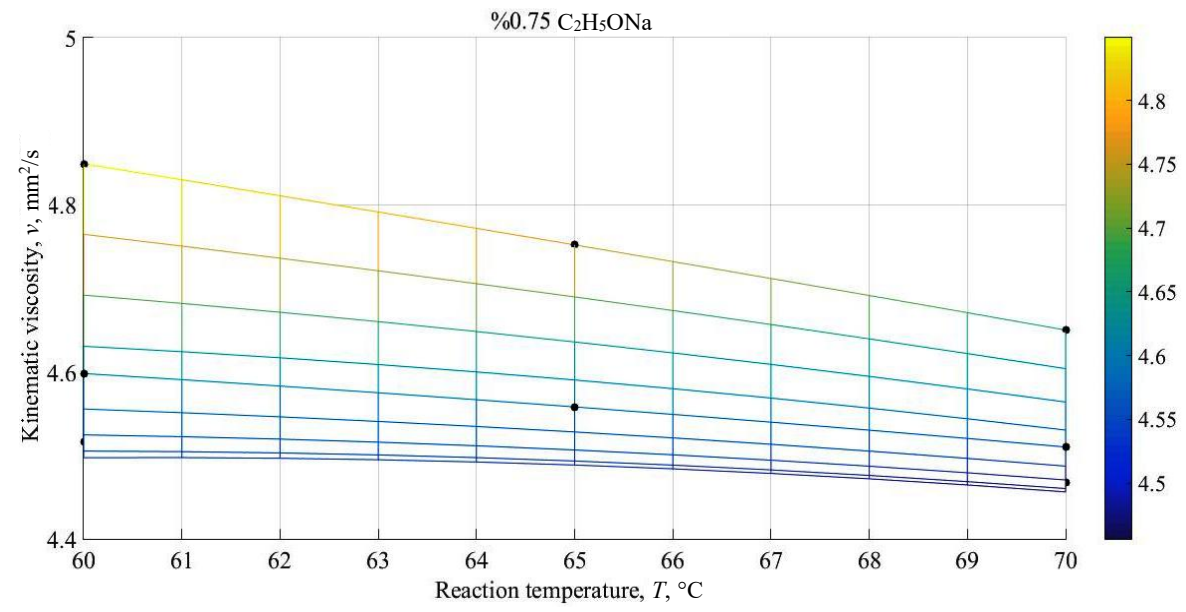

(b)

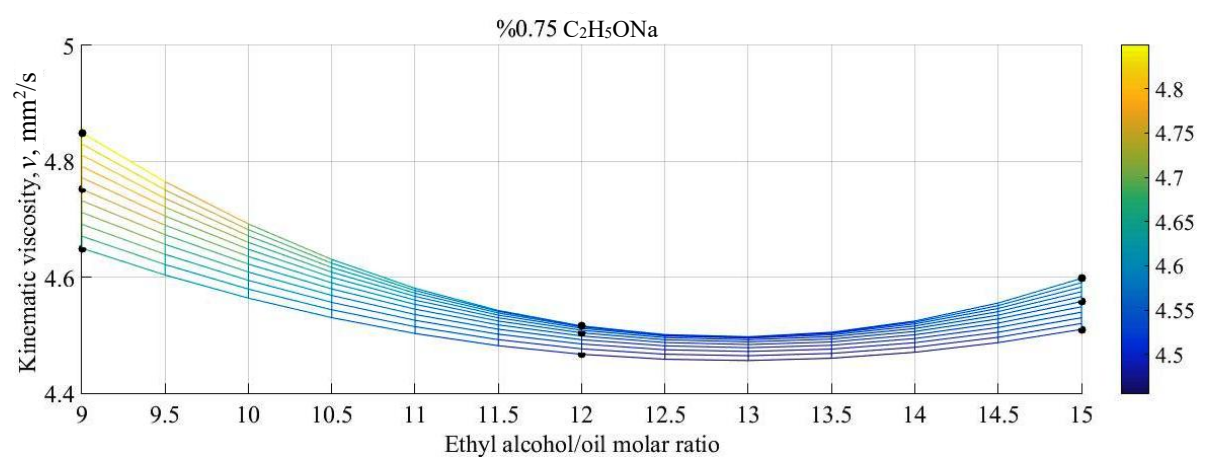

(c)

Fig. 4. Variation in ethyl ester viscosity (a) vs. reaction temperature and alcohol/oil molar ratio simultaneously; (b) alcohol/oil molar ratio; (c) reaction temperature for the catalyst concentration of $0.75 \%$. 


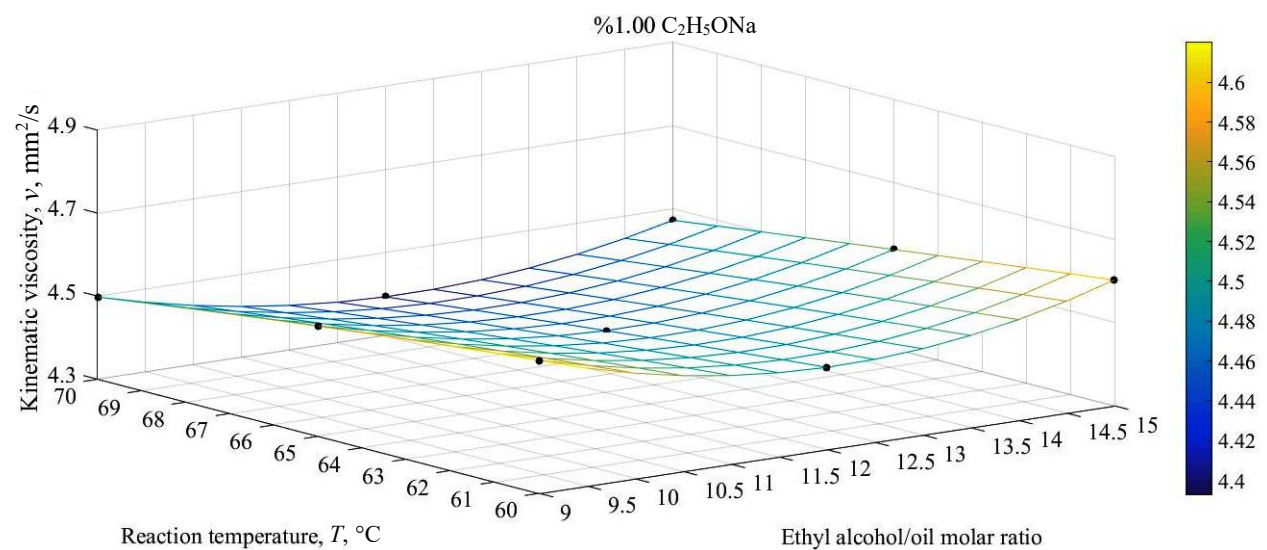

(a)

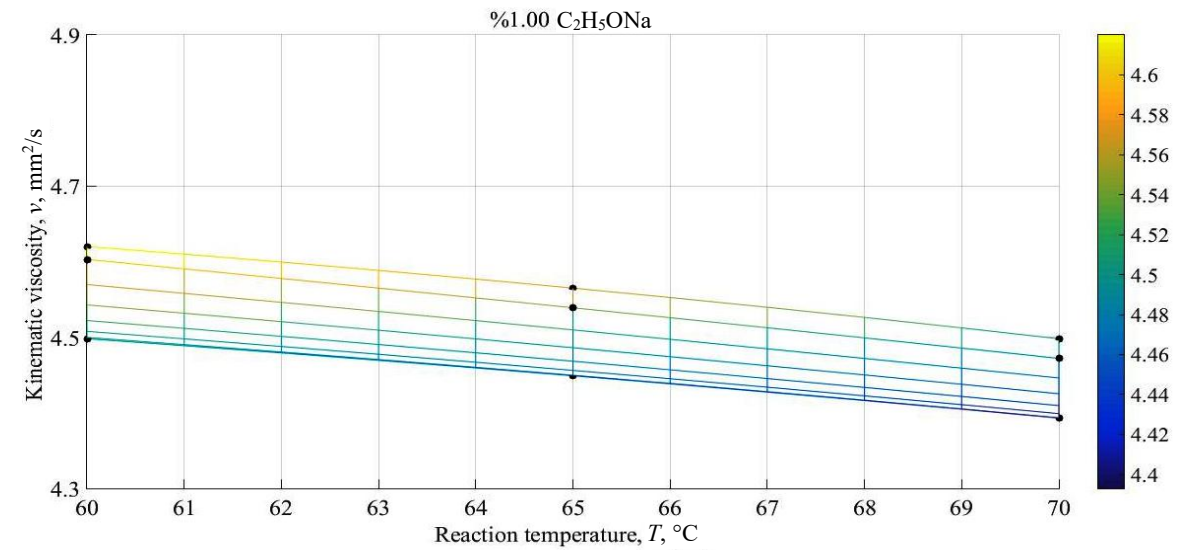

(b)

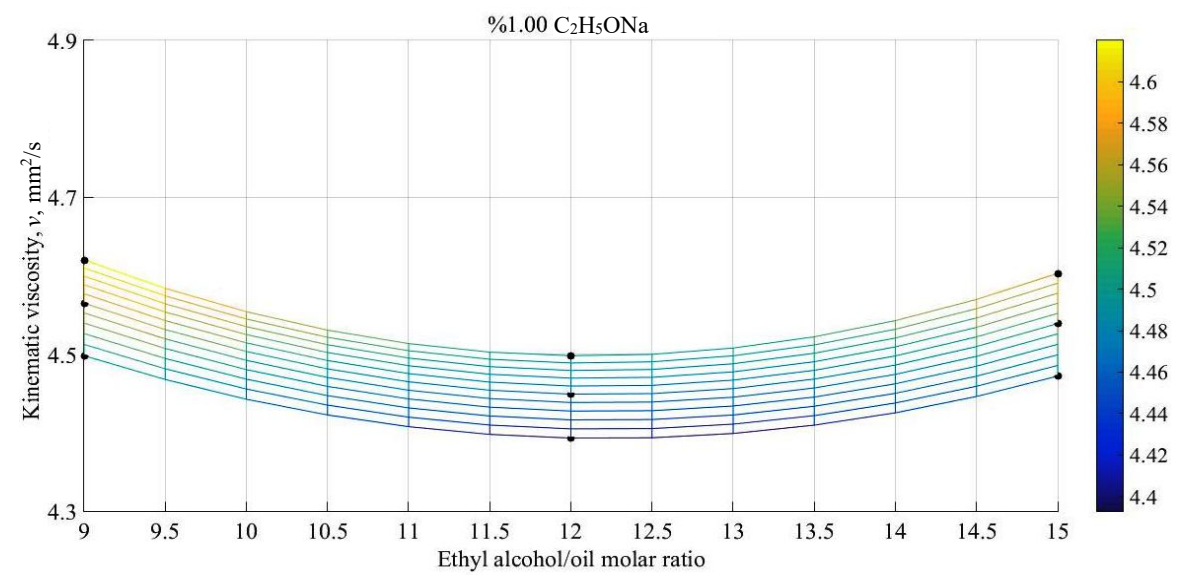

(c)

Fig. 5. Variation in ethyl ester viscosity (a) vs. reaction temperature and alcohol/oil molar ratio simultaneously; (b) alcohol/oil molar ratio; (c) reaction temperature for the catalyst concentration of $1.00 \%$. 
2D Fig. 1-6(c) show the individual effect of reaction temperature on viscosities of methyl and ethyl esters produced using different catalyst concentrations $(0.75 \%, 1.00 \%$ and $1.25 \%)$. As reaction temperature is increased, the transesterification, as an endothermic reaction, shifts to ester side (i.e. conversion yield to biodiesel increases), and viscosities of methyl and ethyl esters diminish until $56^{\circ} \mathrm{C}$ and $70{ }^{\circ} \mathrm{C}$ at which the values reach minimums, given above for all catalyst concentrations, respectively. However, higher reaction temperatures than $56{ }^{\circ} \mathrm{C}$ and $70{ }^{\circ} \mathrm{C}$ cause a decrease in the reaction yield because of evaporation of alcohol from the reaction medium, saponification and decomposition, resulting in the increase in viscosities of methyl and ethyl esters. The variation in viscosities of methyl esters with respect to reaction temperature occurs in a more narrow range when the catalyst concentration of $1.00 \%$ is used, compared to $0.75 \%$ and $1.25 \%$, as seen in 2D Fig. 1-3(c). In addition, the interval of variation in viscosity values of ethyl esters vs. reaction temperature nearly remains for $1.00 \%$ and $1.25 \%$ while the interval decreases for $0.75 \%$ catalyst concentration as the reaction temperature is raised, as seen in Fig. 4-6(c).

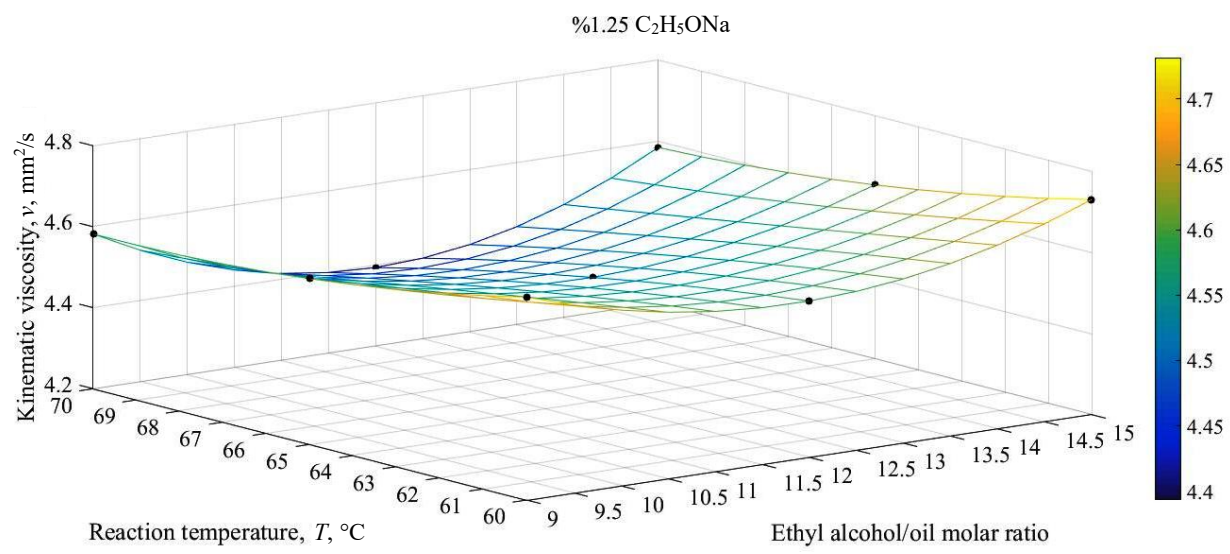

(a)

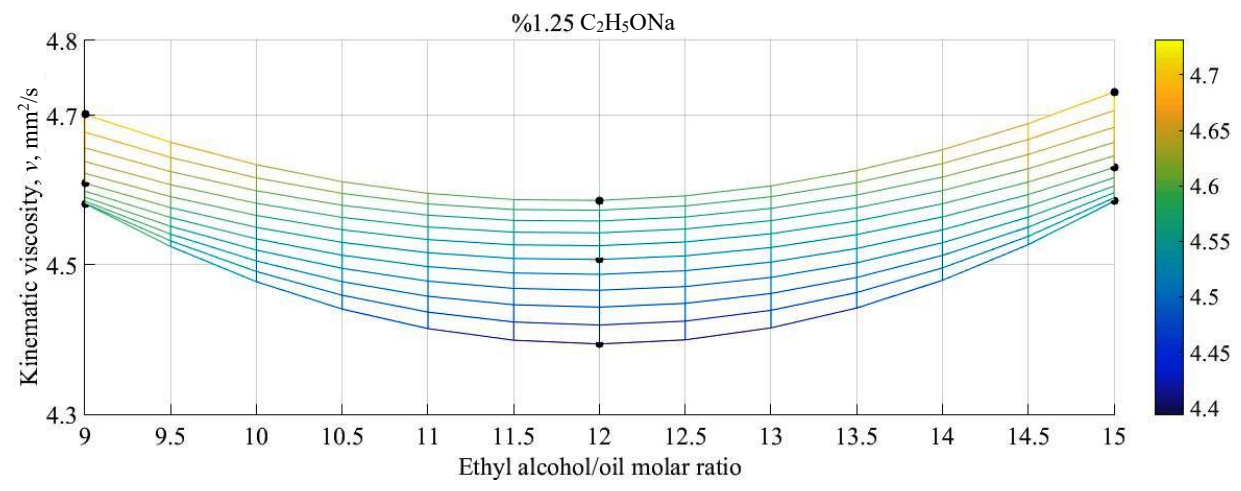

(b) 


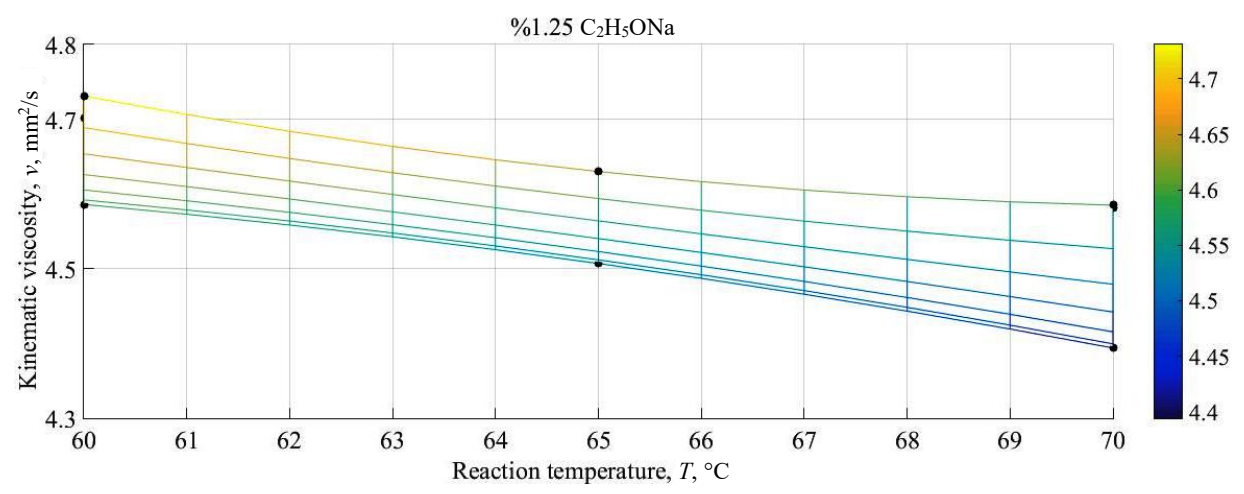

(c)

Fig. 6. Variation in ethyl ester viscosity (a) vs. reaction temperature and alcohol/oil molar ratio simultaneously; (b) alcohol/oil molar ratio; (c) reaction temperature for the catalyst concentration of $1.25 \%$.

In summary, in accordance with the aim of the study mentioned in the introduction section, according to experimental viscosity data (Appendix Table 1), the methyl ester having the lowest viscosity of $4.044 \mathrm{~mm}^{2} / \mathrm{s}$ was produced with the reaction parameters: $0.75 \%$ catalyst concentration, 9:1 methyl alcohol to oil molar ratio, $55^{\circ} \mathrm{C}$ reaction temperature and 90 minutes reaction duration. However, by means of cubic spline interpolation, optimum reaction parameters providing estimated viscosity value of $3.9998 \mathrm{~mm}^{2} / \mathrm{s}$ even lower than experimental value of $4.044 \mathrm{~mm}^{2} / \mathrm{s}$ were determined as: $0.75 \%$ catalyst concentration, 8:1 methyl alcohol to oil molar ratio and $56{ }^{\circ} \mathrm{C}$ reaction temperature, as mentioned above. According to the optimum reaction parameters obtained from spline interpolation, safflower oil methyl ester was synthesized and the viscosity value was obtained as $3.989 \mathrm{~mm}^{2} / \mathrm{s}$, which is very close to the estimated value $\left(3.9998 \mathrm{~mm}^{2} / \mathrm{s}\right)$ and lower than the experimental value of $4.044 \mathrm{~mm}^{2} / \mathrm{s}$. Further, the ethyl ester having the lowest viscosity of $4.393 \mathrm{~mm}^{2} / \mathrm{s}$ was synthesized by means of transesterification carried out at $70{ }^{\circ} \mathrm{C}$, alcohol to oil molar ratio of $12: 1$ and by using catalyst concentration of $1.00 \%$ for 120 minutes, as seen in Appendix Table 2. It was noted here that the ethyl ester having a viscosity of $4.467 \mathrm{~mm}^{2} / \mathrm{s}$ was produced via the reaction parameters: $70{ }^{\circ} \mathrm{C}, 0.75 \%$ and $12: 1$ (Appendix Table 2), although, according to results of cubic spline interpolation, the lower viscosity of $4.450 \mathrm{~mm}^{2} / \mathrm{s}$ than the experimental value of $4.467 \mathrm{~mm}^{2} / \mathrm{s}$ was also obtained with the same parameters except for the higher alcohol to oil molar ratio (13:1). This value is very close to the value of $4.4562 \mathrm{~mm}^{2} / \mathrm{s}$ estimated from spline interpolation, as shown in Fig. 4(b), showing the results obtained from cubic interpolation are highly reliable and accurate.

\section{Conclusions}

Kinematic viscosity is the key fuel property influencing spray characteristics, engine performance and exhaust emissions. The high viscosity of biodiesel causes poor atomization, incomplete combustion and increase in exhaust emissions. Therefore, the importance of this study is to produce the lowest viscosity safflower oil methyl and ethyl esters for solving the high viscosity problem, thus increasing the use of biodiesel in the world. For this, (1) an experimental optimization of methanolysis and ethanolysis reactions was carried out by investigating the effects of catalyst (sodium ethoxide) amount, reaction temperature and alcohol (methyl or ethyl) to oil 
molar ratio on viscosity of produced biodiesel as a full factorial design, and (2) dynamic viscosities and densities of biodiesels were measured in accordance with ISO 4787 and DIN 53015 standards, respectively. In addition, it is thought that this study has the scientific importance since parametric works such as this on production of the lowest viscosity methyl or ethyl ester are rarely performed in existing literature, although, there are many studies on optimization of transesterification reaction parameters giving the highest methyl or ethyl ester yield. Moreover, the use of safflower oil with high potential and low-cost in biodiesel production shows the practical importance of this study. The following conclusions can be drawn from the study:

- Viscosities of methyl esters produced using catalyst concentration of $1.25 \%$ generally take the highest values, compared to $0.75 \%$ and $1.00 \%$, as seen in Appendix Table 1;

- Viscosities of ethyl esters produced using catalyst concentration of $1.00 \%$ are generally the lowest, compared to $0.75 \%$ and $1.25 \%$, as seen in Appendix Table 2;

- Viscosity values of methyl and ethyl esters decrease and lower to a minimum at certain parametric values as reaction temperature or alcohol molar ratio increases. However, when reaction temperature and molar ratio are again increased, the reaction yield decreases and viscosities again tend to increase;

- The catalyst concentration of $0.75 \%$, alcohol to oil molar ratio of $8: 1$, reaction temperature of $56{ }^{\circ} \mathrm{C}$ and reaction duration of 90 minutes provide the lowest viscosity safflower oil methyl ester of $3.989 \mathrm{~mm}^{2} / \mathrm{s}$;

- The lowest viscosity safflower oil ethyl ester of $4.393 \mathrm{~mm}^{2} / \mathrm{s}$ was produced by means of the parameters: $1.00 \%$ catalyst concentration, $12: 1$ alcohol to oil molar ratio, $70{ }^{\circ} \mathrm{C}$ reaction temperature and 120 minutes reaction duration. 


\section{APPENDIX}

TABle 1. Viscosity Data of METhyl Esters PRODUCED ACCORDING TO DIFFERENT PARAMETRIC VALUES

\begin{tabular}{|c|c|c|c|}
\hline $\begin{array}{l}\text { Catalyst } \\
\text { concentration }\end{array}$ & $\begin{array}{l}\text { Methyl alcohol/oil } \\
\text { molar ratio }\end{array}$ & $\begin{array}{l}\text { Reaction temperature } \\
T,{ }^{\circ} \mathrm{C}\end{array}$ & $\begin{array}{l}\text { Kinematic viscosity } \\
v, \mathrm{~mm}^{2} / \mathrm{s}\end{array}$ \\
\hline \multirow{9}{*}{$0.75 \%$} & \multirow{3}{*}{$3: 1$} & 50 & 4.924 \\
\hline & & 55 & 4.662 \\
\hline & & 60 & 4.703 \\
\hline & \multirow{3}{*}{$6: 1$} & 50 & 4.300 \\
\hline & & 55 & 4.100 \\
\hline & & 60 & 4.157 \\
\hline & \multirow{3}{*}{$9: 1$} & 50 & 4.189 \\
\hline & & 55 & 4.044 \\
\hline & & 60 & 4.090 \\
\hline \multirow{9}{*}{$1.00 \%$} & \multirow{3}{*}{$3: 1$} & 50 & 4.878 \\
\hline & & 55 & 4.507 \\
\hline & & 60 & 4.790 \\
\hline & \multirow{3}{*}{$6: 1$} & 50 & 4.763 \\
\hline & & 55 & 4.248 \\
\hline & & 60 & 4.488 \\
\hline & \multirow{3}{*}{$9: 1$} & 50 & 4.997 \\
\hline & & 55 & 4.545 \\
\hline & & 60 & 4.799 \\
\hline \multirow{9}{*}{$1.25 \%$} & \multirow{3}{*}{$3: 1$} & 50 & 5.201 \\
\hline & & 55 & 4.893 \\
\hline & & 60 & 5.092 \\
\hline & \multirow{3}{*}{$6: 1$} & 50 & 4.807 \\
\hline & & 55 & 4.313 \\
\hline & & 60 & 4.555 \\
\hline & \multirow{3}{*}{$9: 1$} & 50 & 4.972 \\
\hline & & 55 & 4.575 \\
\hline & & 60 & 4.764 \\
\hline
\end{tabular}




\section{TABLE 2. Viscosity DATA OF ETHYL ESTERS PRODUCED ACCORDING TO DIFFERENT PARAMETRIC VALUES}

\begin{tabular}{|c|c|c|c|}
\hline $\begin{array}{l}\text { Catalyst } \\
\text { concentration }\end{array}$ & $\begin{array}{l}\text { Ethyl alcohol/oil } \\
\text { molar ratio }\end{array}$ & $\begin{array}{l}\text { Reaction temperature } \\
T,{ }^{\circ} \mathrm{C}\end{array}$ & $\begin{array}{l}\text { Kinematic viscosity } \\
N, \mathrm{~mm}^{2} / \mathrm{s}\end{array}$ \\
\hline \multirow{9}{*}{$0.75 \%$} & \multirow{3}{*}{$9: 1$} & 60 & 4.849 \\
\hline & & 65 & 4.752 \\
\hline & & 70 & 4.650 \\
\hline & \multirow{3}{*}{$12: 1$} & 60 & 4.516 \\
\hline & & 65 & 4.504 \\
\hline & & 70 & 4.467 \\
\hline & \multirow{3}{*}{$15: 1$} & 60 & 4.598 \\
\hline & & 65 & 4.558 \\
\hline & & 70 & 4.510 \\
\hline \multirow{9}{*}{$1.00 \%$} & \multirow{3}{*}{$9: 1$} & 60 & 4.620 \\
\hline & & 65 & 4.565 \\
\hline & & 70 & 4.498 \\
\hline & \multirow{3}{*}{$12: 1$} & 60 & 4.509 \\
\hline & & 65 & 4.449 \\
\hline & & 70 & 4.393 \\
\hline & \multirow{3}{*}{$15: 1$} & 60 & 4.603 \\
\hline & & 65 & 4.539 \\
\hline & & 70 & 4.472 \\
\hline \multirow{9}{*}{$1.25 \%$} & \multirow{3}{*}{$9: 1$} & 60 & 4.701 \\
\hline & & 65 & 4.609 \\
\hline & & 70 & 4.582 \\
\hline & \multirow{3}{*}{$12: 1$} & 60 & 4.586 \\
\hline & & 65 & 4.507 \\
\hline & & 70 & 4.404 \\
\hline & \multirow{3}{*}{$15: 1$} & 60 & 4.731 \\
\hline & & 65 & 4.630 \\
\hline & & 70 & 4.585 \\
\hline
\end{tabular}

\section{REFERENCES}

[1] Zabeti M., Daud W. M. A. W., Aroua M. K. Activity of solid catalysts for biodiesel production: A review. Fuel Processing Technology 2009:90(6):770-7. doi:10.1016/j.fuproc.2009.03.010

[2] Standard specification for biodiesel fuel blend stock (B100) for middle distillate fuels, American Society for Testing and Materials D6751; 2012. doi:10.1520/D6751-15CE01

[3] Gulum M., Bilgin A. Density, flash point and heating value variations of corn oil biodiesel-diesel fuel blends. Fuel Processing Technology 2015:134:456-64. doi:10.1016/j.fuproc.2015.02.026

[4] Shuit S. H., Ong Y. T., Lee K. T., Subhash B., Tan S. H. Membrane technology as a promising alternative in biodiesel production: A review. Biotechnology Advances 2012:30(6):1364-80. doi:10.1016/j.biotechadv.2012.02.009

[5] Smith P. C., Ngothai Y., Nguyen Q. D., O'Neill B. K. Improving the low-temperature properties of biodiesel: Methods and consequences. Renewable Energy 2010:35(6):1145-51. doi:10.1016/j.renene.2009.12.007 
[6] Helwani Z., Othman M. R., Aziz N., Fernando W. J. N., Kim J. Technologies for production of biodiesel focusing on green catalytic techniques: A review. Fuel Processing Technology 2009:90(12):1502-14. doi:10.1016/j.fuproc.2009.07.016

[7] Kalligeros S., Zannikos F., Stournas S., Lois E., Anastopoulos G., Teas C., Sakellaropoulos F. An investigation of using biodiesel/marine diesel blends on the performance of a stationary diesel engine. Biomass and Bioenergy 2003:24(2):141-9. doi:10.1016/S0961-9534(02)00092-2

[8] Demirbas A. Biodiesel from waste cooking oil via base-catalytic and supercritical methanol transesterification. Energy Conversion and Management 2009:50(4):923-7. doi:10.1016/j.enconman.2008.12.023

[9] Gulum M., Bilgin A. A research on reaction parameters about hazelnut oil methyl ester production. Exergetic, energetic and environmental dimensions. Amsterdam; 2017.

[10] De Paola M. G., Ricca E., Calabro V., Curcio S., Iorio G. Factor analysis of transesterification reaction of waste oil for biodiesel production. Bioresource Technology 2009:100(21):5126-31. doi:10.1016/j.biortech.2009.05.027

[11] Gulum M., Bilgin A., Cakmak A. V. Production of the lowest viscosity waste cooking oil biodiesel by using ethanol and potassium hydroxide. Journal of Clean Energy Technologies 2017:5(4):289-93. doi:10.18178/JOCET.2017.5.4.385

[12] Berchmans H. J., Hirata S. Biodiesel production from crude Jatropha curcas L. seed oil with a high content of free fatty acids. Bioresource Technology 2008:99(6):1716-21. doi:10.1016/j.biortech.2007.03.051

[13] Tiwari A. K., Kumar A., Raheman H. Biodiesel production from jatropha oil (Jatropha curcas) with high free fatty acids: An optimized process. Biomass and Bioenergy 2007:31(8):569-75. doi:10.1016/j.biombioe.2007.03.003

[14] Sirisomboonchai S., Abuduwayiti M., Guan G., Samart C., Abliz S., Hao X., Kusakabe K., Abudula A. Biodiesel production from waste cooking oil using calcined scallop shell as catalyst. Energy Conversion and Management 2015:95:242-7. doi:10.1016/i.enconman.2015.02.044

[15] Eevera T., Rajendran K., Saradha S. Biodiesel production process optimization and characterization to assess the suitability of the product for varied environmental conditions. Renewable Energy 2009:34(3):762-5. doi:10.1016/j.renene.2008.04.006

[16] Kirubakaran M., Selvan V. A. M. A comprehensive review of low cost biodiesel production from waste chicken fat. Renewable and Sustainable Energy Reviews 2018:82:390-401. doi:10.1016/j.rser.2017.09.039

[17] Mansir N., Teo S. H., Rashid U., Saiman M. I., Tan Y. P., Alsultan G. A., Taufiq-Yap Y. H. Modified waste egg shell derived bifunctional catalyst for biodiesel production from high FFA waste cooking oil. A review. Renewable and Sustainable Energy Reviews 2018:82:3645-55. doi:10.1016/j.rser.2017.10.098

[18] Bilgin A., Gulum M., Koyuncuoglu I., Nac E., Cakmak A. V. Determination of transesterification reaction parameters giving the lowest viscosity waste cooking oil biodiesel. Social and Behavioral Sciences Procedia 2015:195:2492-500. doi:10.1016/j.sbspro.2015.06.318

[19] Baskar G., Aiswarya R. Trends in catalytic production of biodiesel from various feedstocks. Renewable and Sustainable Energy Reviews 2016:57:496-504. doi:10.1016/j.rser.2015.12.101

[20] Mardhiah H. H., Ong H. C., Masjuki H. H., Lim S., Lee H. V. A review on latest developments and future prospects of heterogeneous catalyst in biodiesel production from non-edible oils. Renewable and Sustainable Energy Reviews 2017:67:1225-36. doi:10.1016/j.rser.2016.09.036

[21] Verma P., Sharma M. P., Dwivedi G. Impact of alcohol on biodiesel production and properties. Renewable and Sustainable Energy Reviews 2016:56:319-33. doi:10.1016/j.rser.2015.11.048

[22] Gulum M., Bilgin A., Cakmak A. V. Comparison of optimum reaction parameters of corn oil biodiesels produced by using sodium hydroxide $(\mathrm{NaOH})$ and potassium hydroxide $(\mathrm{KOH})$. Journal of the Faculty of Engineering and Architecture of Gazi University 2015:30(3):503-11.

[23] Gulum M. Experimental investigation of the effect of various production parameters on the some fuel properties of produced biodiesels from corn and hazelnut oils. Master Thesis. Trabzon: Karadeniz Technical University, 2014.

[24] Rashid U., Anwar F. Production of biodiesel through optimized alkaline-catalyzed transesterification of rapeseed oil. Fuel 2008:87(3):265-73. doi:10.1016/i.fuel.2007.05.003

[25] Holman J. P. Experimental methods for engineers, seventh ed. New York: McGraw-Hill, 2001.

[26] Gulum M., Bilgin A. A comprehensive study on measurement and prediction of viscosity of biodiesel-diesel-alcohol ternary blends. Energy 2018:148:341-361. doi:10.1016/j.energy.2018.01.123 


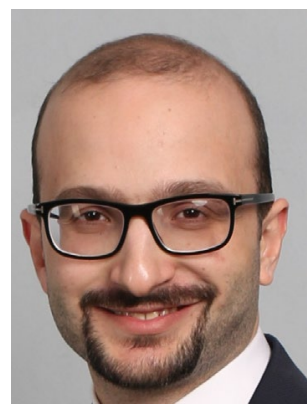

Mert Gulum received B. sc. and Master's degree in Mechanical Engineering at Karadeniz Technical University in 2010 and 2014, respectively. He has been working at Karadeniz Technical University as $\mathrm{PhD}$ candidate research assistant since 2012. His research areas include biodiesel production, combustion, fuels, diesel engines and computational fluid dynamic. Some previous publications include:

1. Gulum M., Bilgin A. Measurements and empirical correlations in predicting biodieseldiesel blends' viscosity and density. Fuel 2017:199:567-77. doi:10.1016/j.fuel.2017.03.001

2. Gulum M., Bilgin A. Two-term power models for estimating kinematic viscosities of different biodiesel-diesel fuel blends. Fuel Processing Technology 2016:149:121-30. doi:10.1016/i.fuproc.2016.04.013

3. Gulum M., Bilgin A. Density, flash point and heating value variations of corn oil biodieseldiesel fuel blends. Fuel Processing Technology 2015:134:456-64.

ORCID: http://orcid.org/0000-0002-1792-3499

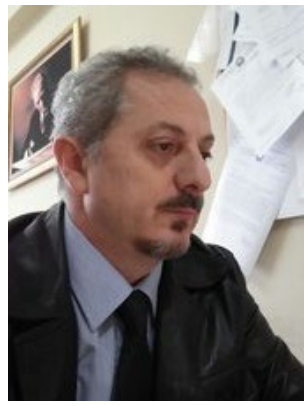

Atilla Bilgin received Master's and PhD degree in Mechanical Engineering at 1988 and 1994 from Karadeniz Technical University, respectively. He is working at Karadeniz Technical University as Full Professor Doctor. His research areas include combustion, fuels, engines, computational fluid dynamic, exergy analysis, thermodynamic cycle analysis. Some previous publications are:

1. Cakmak A. V., Bilgin A. Exergy and energy analysis with economic aspects of a diesel engine running on biodiesel-diesel fuel blends. International Journal of Exergy 2017:24(24):151-72. doi:10.1504/IJEX.2017.087700

2. Sezer I., Bilgin A. Effects of charge properties on exergy balance in spark ignition engine. Fuel 2013:112:523-30. doi:10.1016/j.fuel.2012.09.078

3. Bilgin A., Sezer I. Effects of methanol addition to gasoline on the performance and fuel cost of a spark ignition engine. Energy \& Fuels 2008:22(4):2782-8. doi:10.1021/ef8001026 4. Bilgin A., Durgun O., Sahin Z. The effects of diesel-ethanol blends on diesel engine performance. Energy sources 2002:24(5):431-40. doi:10.1080/00908310252889933 